\title{
Foreword COVID 19 SPECIAL EDITION
}

COVID 19冠状病毒特刊前言

Debra Kamanowitz

Academic College of Society and the Arts (ASA), Israel

\begin{abstract}
This foreword is an introduction to the COVID 19 special edition. It speaks to the articles submitted for this special edition, and the role of art at the time of this pandemic
\end{abstract}

Keywords: art, corona virus, collective trauma, pandemic, society, transformation

\section{摘要}

这篇前言是对新冠疫情 (COVID 19) 特刊的介绍。它提及了为这期特刊投稿的文章，以 及艺术在这次全球性流行病中的作用。

关键词 : 艺术, 冠状病毒, 集体创伤, 全球性流行病, 社会, 转化

The story of the corona virus began on December 31, 2019 when the government in China confirmed that they were treating multiple cases of a new virus, later named the novel Coronavirus or COVID-19. As the months have unfolded, so have the chapters of this pandemic. While the entire globe has been affected, we are all at different stages of infection. Some are only at the beginning, others in the middle, while others may even be moving towards recovery.

I am no expert on the corona virus. I am, however, an artist and art therapist and what I have come to understand is that at times like these, people look towards therapists and artists amongst others; for example, clergymen or the government for answers. The fact is none of us know the answers. This is the predicament with which we are faced. There is much confusion and uncertainty around this invisible threat. In these times meeting a friend can be dangerous, a walk down the road is uncertain, ordinary, every-day life is a threat.

Social isolation and physical distancing have reinforced a sense of immobilization and loneliness. What I have seen as emerging for some is fear, anxiety, depression, disempowerment, loss of meaning (emptiness), a sense of disintegration and direction and inextricable grief and loss, but most of all helplessness.

Feeling helpless/losing control, is one of the primary aspects we address when working with trauma and in situations of crisis. All of us have struggled with this at these times. Stuck in our houses, in isolation, the things that we have traditionally done to make us feel useful have been halted, leaving us in a vacuum and have all responded differently.

When I look towards our collective experiences, across the world, across humanity and in the submissions for this special edition, I am struck not just by what we don't 
know, but also by what has emerged. The overwhelming evidence of the capacity of the arts to hold a space. The arts have allowed for embodied connection, balance and kindness as well as to assist in the reconnection to nature and to the nature of our reality $(t a o)$. The Chinese word tao signifies "the way things are", the nature of our current reality, the universe and human life at this time.

The arts as expressed in this special edition have by their very nature done just this. Rather than seeking fast solutions, they have evolved organically as a personal and social response, not just for the individual, but for the entire world. Many of the articles have outlined a reciprocal relationship between us and our environments. Virus, says Chen Yang in his contribution, "follow(s) the laws of nature to evolve for their own survival" and in many ways so must we. Some of us are better at this than others. The arts have revealed themselves over this time and over time as integral to this process.

Guo Haiping in this special edition writes that "Art transforms our personal destiny into the destiny of all humans". Indeed, behind the crisis of the virus, lies a crisis of human relationships, with each other and with nature. This virus seems to have further exposed a collective pattern of disconnection and fear. Disconnection from ourselves, society and nature. Fear of trusting ourselves and others, fear of the virus, fear of the disparities around the world, racism (Black Lives Matter), stigma, fear of the news the "infodemic" (Guterres, 2020), the virus of social media and primarily amongst the youth, a fear for our environment as epitomized by Greta Thunberg's impassioned appeals to the leaders of the world to take decisive actions to save our planet.

Collective trauma refers to the psychological turmoil that is shared by a group of people who all experience the same or similar event. This pandemic is unfolding as a force of nature, prolonged and extended beyond our imagination across the world. We are coming to terms with our new reality and the realization that the psychological, social and economic impacts still remain to be seen. Collective traumas leave a mark on both individuals and on society as a whole and can disrupt our understanding of the world as well as or our own individual worlds and change the way we view ourselves, our society and others. Like all things that are damaging, they also transform but we are still in the midst of the pandemic. Science is searching for a vaccine, across the globe, people are re-aligning their expectations and the arts continue to allow for the uncanny to be juxtaposed with the familiar like a David Lynch movie (Robson, 2020). The articles in this special edition are testament to this. The arts allow us to be with what is, as it is, to reside in a space in which we as yet, have no solutions.

\section{About the Author}

Dr. Debra KALMANOWITZ, PhD, HCPC, BAAT reg. art therapist, artist and co-editor in Chief of the Journal CAET. Debra works in the context of humanitarian aid, disaster relief, political violence, refugees and social change and has done since the early 1990's. She held positions at the Medical Foundation for Victims of Torture, London and Christian Action, Hong Kong where she worked with refugees. She is a practicing artist and art therapist, assistant Professor at the Academic College of Society and the Arts (ASA), lecturer at Bar Ilan University (Israel), and is a psychosocial facilitator for the international non-government organisation (NGO), IsraAid. She is the co-author of 
The Portable Studio, Art Therapy and Political Violence: With art, without illusion and Art Therapy in Asia: To the Bone or Wrapped in Silk.

\section{References}

Robson, D. (2020, May 18). Psyche. A Touch of Absurdity can help our mind around reality. Viewed July 5 , 2020, in https://psyche.co/ideas/a-touch-of-absurdity-can-help-to-wrap-your-mind-around-reality

Guterres, A. (2020, March 31). UN tackles 'infodemic' of misinformation and cybercrime in COVID19 crisis, viewed 8.7.2020. https://www.un.org/en/un-coronavirus-communications-team/un-tackling$\%$ E2\%80\%98infodemic $\%$ E2\%80\%99-misinformation-and-cybercrime-covid-19 